\title{
Comparison of Caralluma tuberculata with Metformin for Anti- Diabetic Activity: An Animal Study
}

\author{
Muhammad Saleh Faisal ${ }^{1}$, Waqar Hayat ${ }^{2}$, Asad Inayat ${ }^{3}$, Muhammad Sohaib ${ }^{4}$, Waheed Iqbal 5 \\ ${ }^{1}$ Assistant Professor, Department of Pharmacology - Khyber Medical College, Peshawar \\ ${ }^{2}$ Trainee Medical Officer, Department of Medicine - Khyber Teaching Hospital, Peshawar \\ ${ }^{3}$ Trainee Medical Officer, Department of Medicine - Khyber Teaching Hospital, Peshawar \\ ${ }^{4}$ Research Assistant, Khyber Medical University, Peshawar \\ ${ }^{5}$ Chemist, Department of Pharmacology, Khyber Medical College, Peshawar
}

\section{A B S T RACT}

\begin{abstract}
Background: Caralluma tuberculata, is a wild herb, which grows in the hills of Balochistan and has been known to have medicinal and nutritional properties since antiquity. This experimental research was designed to study the hypoglycemic properties of Caralluma tuberculata and to compare them with Metformin.

Material and Methods: This was a laboratory-based animal experimental study. It was conducted in the Pharmacology laboratory of Khyber Medical University, Peshawar from February 2016 to August 2016. Two types of extracts of Caralluma tuberculata [crude extract and carbon tetrachloride ( $\mathrm{CCl} 4)$ extract] were prepared and administered to normal and alloxan treated diabetic rabbits. To study anti-diabetic activity, eighty-four rabbits were divided into two main groups. Group I (Normal/Non-Diabetic Rabbits; $n=21$ ) and Group II (Diabetic/Alloxanized Rabbits; $n=63$ ). Each group was further divided into sub-groups (7 rabbits in each). Effect of Caralluma tuberculata, Metformin and $2 \%$ gum tragacanth on blood glucose levels were checked at 0, 2, 4, 6, 8, 12 and 24 hours of drug administration. The extracts were given in capsule form and in cooking oil. Data analysis was done using SPSS version 16 . For calculation and comparison of the hypoglycemic effects at various doses and different time intervals, analysis of variance (ANOVA) and Tukey's post hoc test were applied.
\end{abstract}

Results: The crude extract, $200 \mathrm{mg} / \mathrm{kg}$ body weight of Caralluma tuberculata showed significant decrease $(p<0.001)$ in mean blood glucose levels from 2-hour till12 hours. Whereas, highly significant reduction of blood glucose was seen from 2 hours after treatment till 24 hours, when carbon tetrachloride $\left(\mathrm{CCl}_{4}\right)$ fraction of Caralluma $(100 \mathrm{mg} / \mathrm{kg}$ body weight) in capsule form was administered. Metformin $500 \mathrm{mg} / \mathrm{kg}$ body weight was given to compare its effects with plant crude extract and it was found that metformin appeared to be less effective in comparison with Caralluma tuberculata.

Conclusion: Caralluma tuberculata lowered the blood glucose level and turned out to be more significant in developing hypoglycemia when taken with cooking oil. More work is essential to provide stronger evidence for the use of this natural agent in the management of Diabetes Mellites.

Key words: Anti-diabetic, Caralluma tuberculata, Hypoglycaemic

\begin{tabular}{lll}
\hline Authors' Contribution: & Correspondence: & Article info: \\
1,2 Conception, synthesis, planning of & Waheed lqbal & Received: July 22, 2018 \\
research and manuscript writing ${ }^{3-5}$ & Email: waheediqbal22@gmail.com & Accepted: November 10, 2018 \\
Interpretation, discussion, Data analysis, & &
\end{tabular}
Active participation in data collection.

Cite this article: Faisal MS, Hayat W, Inayat A, Sohaib M, Iqbal W. Comparison of Caralluma Tuberculata with Metformin for anti-diabetic activity: An animal study. J Islamabad Med Dental Coll.2019; 8(1):34-39

\section{Introduction}

Diabetes mellitus is one of the most common metabolic disorders which occur either due to insufficient insulin release (Type 1 diabetes) or tissue resistance to insulin
(Type 2 diabetes). There were around 382 million diabetic patients in the year 2013, and it is estimated that this figure is going to flare up to 592 million by 2035. Most of 
the diabetic patients reside in lower to middle developed countries. ${ }^{1}$ Prevalence of diabetes in rural areas of Pakistan constitutes $7 \%$ and $2.5 \%$ for men and women respectively, while in urban areas this figure is about $6 \%$ for men and 3\% for women. According to another study, the glucose intolerance in urban areas is $14.2 \%$ for women and $6.3 \%$ for men versus $10.9 \%$ for women and $6.9 \%$ for men in rural areas. $^{2}$

There are many plants which have been reported due to their traditional use as anti-diabetic agents, like momordica charantia, citrullus colocynthis, allium sativum, opuntia, aloe and artemisia.,4 In many Indian traditional approaches like Ayurveda, about 800 different medicinal plants have been identified to have hypoglycemic activity, but very few of them got scientific scrutiny. ${ }^{5}$ Valuable information is available about phytochemical components responsible for hypoglycemic effect. The isolation of glycans from plant families such as, granmineae, ranunculaceae and extraction of glycosides from scrophulariaceae, rhamnaceae, caesalpiniaceae and papaveraceae are good examples of this. Moreover, some triterpenes from ranunculaceae, saponins of malvaceae and alkaloids of apocyanaceae have been reported for their hypoglycemic effect. 6,7 However, the search for newer plants with anti-diabetic activity is still in progress.

Caralluma tuberculata, which belongs to family Asclepiadaceae is a wild herb, grows in most of the hilly areas of Balochistan and is used as a vegetable since centuries. Caralluma species have been used by humans as tonic, carminative, anti-helminthic and anti-tumor agent. ${ }^{8}$ Caralluma is reported to be effective in rheumatism and also known to have hypotensive effect., 9,10 The phytochemical constituents include volatile alkaloids, cardiac glycosides, flavonoids, saponins, sterols and tannins. ${ }^{11}$ Adnanet al reported that Caralluma when hydrolyzed under mild conditions gives cymarose, sarmentose, oleandrose or digitoxose as sugar component while work of Bashir et al identified its various nutritional aspects and composition. 12,13

This study was an attempt first to evaluate the hypoglycemic activity of crude and carbon tetrachloride $\left(\mathrm{CCl}_{4}\right)$ extracts of Caralluma tuberculata and then to compare this hypoglycemic activity with metformin.

\section{Material and Methods}

This experimental study was carried out at the Department of Pharmacology, Khyber Medical University, Peshawar from February 2016 to August 2016. Institutional approval was obtained and all the ethical issues pertaining to animal pain and distress, feeding, caging etc. were addressed according to standard protocols for animal studies. Healthy male rabbits weighing $1 \mathrm{~kg}$ to $1.5 \mathrm{~kg}$ of Oryctologus cunniculus species were selected and kept in animal house for one week under strict observation where they were fed upon clean water and fresh fodder. To induce diabetes in normal rabbits, Alloxan monohydrate was injected in a dose of $150 \mathrm{mg} / \mathrm{kg}$ body weight using tuberculin syringe. A week later, blood levels of glucose were determined by glucose oxidase method and only those rabbits were included in the study whose blood glucose level was in the range $300-500 \mathrm{mg} / 100 \mathrm{ml} .14,15$ To study anti-diabetic activity, eighty-four rabbits were divided into two main groups. Group I (Normal/Non-Diabetic Rabbits; $n=21$ ) and Group II (Diabetic/Alloxanized Rabbits; n=63). Each group was further divided into sub-groups (7 rabbits in each, as the minimum number in each group is 6 in already established protocols). ${ }^{15}$

Group 1 ( $\mathrm{n}=21$ ) was further subdivided into following 3 subgroups:

Subgroup $\mathbf{A}_{1}$ : Treated with crude extract of Caralluma tuberculata $200 \mathrm{mg} / \mathrm{kg}$ body weight.

Subgroup $B_{1}$ : Treated with Metformin $500 \mathrm{mg} / \mathrm{kg}$ body weight.

Subgroup $C_{1}$ : Serving as control receiving $20 \mathrm{ml} 2 \%$ gum tragacanth solution.

Group II ( $n=63$ ) was further divided into following 9 subgroups:

Subgroup $\mathrm{A}_{2}$ : Treated with crude extract of Caralluma tuberculata $200 \mathrm{mg} / \mathrm{kg}$ body weight (capsule form).

Subgroup $\mathbf{B}_{2}$ : Treated with Metformin $500 \mathrm{mg} / \mathrm{kg}$ body weight.

Subgroup $\mathrm{C}_{2}$ : Serving as control receiving $20 \mathrm{ml} 2 \%$ gum tragacanth solution.

Subgroup $\mathrm{A}_{3}$ : Treated with $\mathrm{CCl}_{4}$ of Caralluma tuberculata $100 \mathrm{mg} / \mathrm{kg}$ body weight (capsule form).

Subgroup $\mathrm{B}_{3}$ : Treated with Metformin $500 \mathrm{mg} / \mathrm{kg}$ body weight. 
Subgroup $\mathrm{C}_{3}$ : Serving as control receiving $20 \mathrm{ml} 2 \%$ gum tragacanth solution.

Subgroup $\mathrm{A}_{4}$ : Treated with $\mathrm{CCl}_{4}$ of Caralluma tuberculata $100 \mathrm{mg} / \mathrm{kg}$ body weight (in cooking oil).

Subgroup $\mathrm{B}_{4}$ : Treated with Metformin $500 \mathrm{mg} / \mathrm{kg}$ body weight.

Subgroup $\mathrm{C}_{4}$ : Serving as control receiving $20 \mathrm{ml}$ soy bean cooking oil.

The aerial part of the plant was washed and air dried. The dried material was grinded, passed through a mesh and put in distilled water at room temperature for several days, followed by squeezing in a muslin cloth. This procedure was repeated thrice, which as a result produced green syrupy residue. Fractionation of crude extract of Caralluma tuberculata was carried out by suspending the crude extract in water, partitioned with carbon tetrachloride $\left(\mathrm{CCl}_{4}\right)$ by vigorous shaking in a separating funnel. The $\mathrm{CCl}_{4}$ layer was separated and evaporated under reduced pressure in rotary evaporator. The resultant residue was then treated with methanol. The methanol soluble fraction was separated from the insoluble (water soluble) material and evaporated in rotary evaporator.

Effect of Caralluma tuberculata, Metformin and 2\% gum tragacanth on blood glucose levels were checked at 0,2 , $4,6,8,12$ and 24 hours of drug administration.

Data analysis was done using SPSS version 16 and expressed as Mean \pm SD. For calculation and comparison of the hypoglycemic effects at various doses $\&$ different time intervals, analysis of variance (ANOVA) and Tukey's post hoc test were applied.

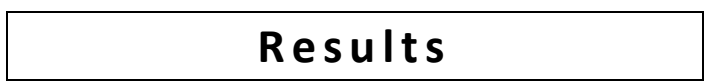

In non-diabetic group, treatment with crude extract of Caralluma produced significant reduction in mean blood glucose levels at 2 hours $(p<0.001), 4$ hours $(p<0.001) 8$ hours $(p<0.001)$ and 12 hours, but gradual increase in blood glucose levels was seen at 24 hours as compared to that at 12 hours interval $(p<0.001)$. However, with metformin, the blood glucose levels decreased after 2 and 4-hours interval but they started increasing from 8 to 24 hours interval after treatment. This increase was significantly high as compared to that at 12 hours interval $(p<0.01)$. Oral administration of $20 \mathrm{ml} 2 \%$ gum tragacanth suspension did not produce any appreciable decrease in blood glucose level (Table I).

When capsule form of Caralluma crude extract was given, significant reduction in blood glucose levels were observed at 2, 4, 8, 12- and 24-hours interval $(p<0.001)$ as compared to that at zero hour $(p>0.1)$ (Table II). Compared to 2 hours interval, there was no significant decrease in blood glucose levels at 4 hours interval $(p=0.2)$ and 8 hours interval $(p=0.2)$. There was significant decrease in blood glucose levels at 12 hours interval compared to that at 8 hours interval $(p<0.05)$ and highly significant increase at 24 hours interval compared to that at 12 hours interval $(p<0.001)$.

\begin{tabular}{|c|c|c|c|}
\hline \multicolumn{4}{|c|}{$\begin{array}{l}\text { Table I: Blood glucose levels after oral administration of crude } \\
\text { extract of Caralluma tuberculata, Metformin and } 2 \% \text { Gum } \\
\text { tragacanth in non-diabetic rabbits ( } n=21 \text { ) }\end{array}$} \\
\hline $\begin{array}{c}\text { Time } \\
\text { interval }\end{array}$ & $\begin{array}{l}\text { Crude extract } \\
200 \mathrm{mg} / \mathrm{kg} \\
\text { body weight }\end{array}$ & $\begin{array}{l}500 \mathrm{mg} / \mathrm{kg} \\
\text { body } \\
\text { weight }\end{array}$ & $20 \mathrm{ml}$ \\
\hline \multirow[t]{2}{*}{ (Hours) } & $\begin{array}{l}\text { Caralluma } \\
\text { tuberculate } \\
\mathrm{A}_{1} ;(\mathrm{n}=07)\end{array}$ & $\begin{array}{l}\text { Metformin } \\
B_{1 ;}(n=07)\end{array}$ & $\begin{array}{c}2 \% \text { Gum } \\
\text { tragacanth } \\
C_{1 ;}(n=07)\end{array}$ \\
\hline & $\begin{array}{l}\text { Blood glucose } \\
(\mathrm{mg} / \mathrm{dl}) \\
\text { mean } \pm \mathrm{SD}\end{array}$ & $\begin{array}{l}\text { Blood } \\
\text { glucose } \\
\text { (mg/dl) } \\
\text { mean } \pm S D\end{array}$ & $\begin{array}{l}\text { Blood glucose } \\
(\mathrm{mg} / \mathrm{dl}) \\
\text { mean } \pm S D\end{array}$ \\
\hline 0 & $104.33 \pm 1.33$ & $92.16 \pm 0.83$ & $94.17 \pm 0.60$ \\
\hline 2 & $79.67 \pm 2.96$ & $82.00 \pm 0.96$ & $94.00 \pm 0.58$ \\
\hline 4 & $73.17 \pm 2.64$ & $72.50 \pm 1.31$ & $94.33 \pm 0.81$ \\
\hline 8 & $80.33 \pm 2.23$ & $79.66 \pm 1.76$ & $93.50 \pm 0.67$ \\
\hline 12 & $72.50 \pm 0.88$ & $87.16 \pm 0.75$ & $91.67 \pm 0.50$ \\
\hline 24 & $99.50 \pm 1.61$ & $92.00 \pm 0.57$ & $92.50 \pm 1.05$ \\
\hline
\end{tabular}

Table II: Blood glucose levels after oral administration of crude extract of Caralluma tuberculata (capsule form), Metformin and $2 \%$ Gum tragacanth in diabetic rabbits $(n=21)$

\begin{tabular}{|c|c|c|c|}
\hline $\begin{array}{l}\text { Time } \\
\text { interval }\end{array}$ & $\begin{array}{l}\text { Crude extract } \\
200 \mathrm{mg} / \mathrm{kg} \\
\text { body weight } \\
\text { (Capsule form) }\end{array}$ & $\begin{array}{c}500 \mathrm{mg} / \mathrm{kg} \\
\text { body weight }\end{array}$ & $20 \mathrm{ml}$ \\
\hline (Hours) & $\begin{array}{c}\text { Caralluma } \\
\text { tuberculate } \\
\mathrm{A}_{2 ;}(\mathrm{n}=07) \\
\end{array}$ & $\begin{array}{l}\text { Metformin } \\
B_{2 ;}(n=07)\end{array}$ & $\begin{array}{l}2 \% \text { Gum } \\
\text { tragacanth } \\
C_{2 ;}(n=07)\end{array}$ \\
\hline & $\begin{array}{c}\text { Blood glucose } \\
(\mathrm{mg} / \mathrm{dl}) \\
\text { mean } \pm \mathrm{SD}\end{array}$ & $\begin{array}{c}\text { Blood glucose } \\
(\mathrm{mg} / \mathrm{dl}) \\
\text { mean } \pm \mathrm{SD}\end{array}$ & $\begin{array}{c}\text { Blood glucose } \\
(\mathrm{mg} / \mathrm{dl}) \\
\text { mean } \pm \mathrm{SD}\end{array}$ \\
\hline 0 & $318.16 \pm 2.05$ & $335.16 \pm 3.04$ & $309.00 \pm 1.62$ \\
\hline 2 & $268.00 \pm 2.61$ & $318.50 \pm 2.96$ & $309.66 \pm 1.78$ \\
\hline 4 & $263.00 \pm 1.24$ & $306.50 \pm 1.65$ & $309.00 \pm 0.89$ \\
\hline 8 & $269.33 \pm 1.97$ & $322.66 \pm 3.08$ & $309.16 \pm 3.25$ \\
\hline 12 & $260.33 \pm 1.50$ & $327.00 \pm 2.50$ & $312.00 \pm 2.85$ \\
\hline 24 & $287.83 \pm 3.52$ & $340.80 \pm 3.63$ & $310.33 \pm 2.50$ \\
\hline
\end{tabular}


In comparison with metformin, capsule form of Caralluma crude extract showed significantly low mean blood glucose levels at 2 hours interval $(p<0.001), 4$ hours interval $(p<0.001), 8$ hours interval $(p<0.001), 12$ hours interval $(p<0.001)$ and 24 hours interval $(p<0.001)$. Oral administration of $2 \%$ gum tragacanth did not produce any appreciable decrease in blood glucose levels.

After oral administration of $\mathrm{CCl} 4$ fraction of Caralluma in capsule, blood glucose levels dropped markedly at 2 hours interval as compared to zero hour $(p<0.001)$. But increase in mean blood glucose levels was observed at 8 , 12 and 24 hours. In comparison with metformin and 2\% gum tragacanth, $\mathrm{CCl} 4$ fraction of Caralluma significantly lowered the blood glucose levels at 2 hours interval $(p<0.001) ; 4$ hours interval $(p<0.001) ; 8$ hours intervals $(p<0.001) ; 12$ hours intervals $(p<0.001)$ and 24 hours intervals $(p<0.001)$ (Table III).

Table IV shows that $\mathrm{CCl} 4$ fraction of Caralluma in soy bean cooking oil caused significant reduction in blood glucose levels at 2, 4, 8, 12- and 24-hours intervals $(p<0.001)$. There was significant difference in blood glucose levels in all groups at 4 hours interval compared to that at 2 hours interval $(p<0.05)$. No significant increase in comparison at 4 hours vs. 8 hours ( $p=0.2) ; 8$ hours vs 12 hours $(p=0.2)$ and 12 hours vs 24 hours $(p=0.2$ ) was observed in groups A4, B4 and C4. After treatment with $20 \mathrm{ml}$ cooking oil, no appreciable difference in mean blood glucose levels was observed. This experiment was maintained as control against treatment groups.

\begin{tabular}{|c|c|c|c|}
\hline \multicolumn{4}{|c|}{$\begin{array}{l}\text { Table III: Blood glucose levels after oral administration of } \\
\text { CCI4 fractions of Caralluma tuberculata (capsule form), } \\
\text { Metformin and } 2 \% \text { Gum tragacanth in diabetic rabbits }(n=21)\end{array}$} \\
\hline $\begin{array}{c}\text { Time } \\
\text { interval }\end{array}$ & $\begin{array}{c}\mathrm{CCl}_{4} \text { fraction } \\
100 \mathrm{mg} / \mathrm{kg} \text { body } \\
\text { weight } \\
\text { (capsule form) }\end{array}$ & $\begin{array}{l}500 \mathrm{mg} / \mathrm{kg} \\
\text { body weight }\end{array}$ & $20 \mathrm{ml}$ \\
\hline \multirow[t]{2}{*}{ (Hours) } & $\begin{array}{l}\text { Caralluma } \\
\text { tuberculate } \\
\mathrm{A}_{3} ;(\mathrm{n}=07)\end{array}$ & $\begin{array}{l}\text { Metformin } \\
B_{3 ;}(n=07)\end{array}$ & $\begin{array}{l}2 \% \text { Gum } \\
\text { tragacanth } \\
C_{3 ;}(n=07)\end{array}$ \\
\hline & $\begin{array}{l}\text { Blood glucose } \\
\quad(\mathrm{mg} / \mathrm{dl}) \\
\text { mean } \pm S D\end{array}$ & $\begin{array}{l}\text { Blood } \\
\text { glucose } \\
(\mathrm{mg} / \mathrm{dl}) \\
\text { mean } \pm \text { SD }\end{array}$ & $\begin{array}{l}\text { Blood glucose } \\
\quad(\mathrm{mg} / \mathrm{dl}) \\
\text { mean } \pm \text { SD }\end{array}$ \\
\hline 0 & $309.50 \pm 1.38$ & $335.16 \pm 3.04$ & $309.00 \pm 1.62$ \\
\hline 2 & $194.16 \pm 2.49$ & $318.50 \pm 2.96$ & $309.66 \pm 1.78$ \\
\hline 4 & $184.16 \pm 3.73$ & $306.50 \pm 1.65$ & $309.00 \pm 0.89$ \\
\hline 8 & $207.67 \pm 3.68$ & $322.66 \pm 3.08$ & $309.16 \pm 3.25$ \\
\hline 12 & $206.67 \pm 2.59$ & $327.00 \pm 2.50$ & $312.00 \pm 2.85$ \\
\hline 24 & $257.33 \pm 3.66$ & $340.80 \pm 3.63$ & $310.33 \pm 2.50$ \\
\hline
\end{tabular}

\begin{tabular}{|c|c|c|c|}
\hline \multicolumn{4}{|c|}{$\begin{array}{l}\text { Table IV: Blood Glucose levels after oral administration of } \\
\text { CCI4 fractions of Caralluma tuberculata (in cooking oil), } \\
\text { Metformin and } 20 \mathrm{ml} \text { Soybean cooking oil as control in } \\
\text { diabetic rabbits }(\mathrm{n}=21)\end{array}$} \\
\hline $\begin{array}{c}\text { Time } \\
\text { interval }\end{array}$ & $\begin{array}{l}\mathrm{CCl} / 4 \text { fraction } \\
100 \mathrm{mg} / \mathrm{kg} \text { body } \\
\text { weight } \\
\text { (In cooking oil) }\end{array}$ & $\begin{array}{l}500 \mathrm{mg} / \mathrm{kg} \\
\text { body } \\
\text { weight }\end{array}$ & $20 \mathrm{ml}$ \\
\hline \multirow[t]{2}{*}{ (Hours) } & $\begin{array}{l}\text { Caralluma tuberculate } \\
\qquad A_{4 ;}(n=07)\end{array}$ & $\begin{array}{l}\text { Metformin } \\
B_{4 ;}(n=07)\end{array}$ & $\begin{array}{l}\text { Soy Bean } \\
\text { cooking oil } \\
C_{4 ;}(n=07)\end{array}$ \\
\hline & $\begin{array}{l}\text { Blood glucose }(\mathrm{mg} / \mathrm{dl}) \\
\text { mean } \pm S D\end{array}$ & $\begin{array}{l}\text { Blood } \\
\text { glucose } \\
\text { (mg/dl) } \\
\text { mean } \pm S D\end{array}$ & $\begin{array}{l}\text { Blood } \\
\text { glucose } \\
(\mathrm{mg} / \mathrm{dl}) \\
\text { mean } \pm \text { SD }\end{array}$ \\
\hline 0 & $287.55 \pm 1.96$ & $335.16 \pm 3.04$ & $301.00 \pm 2.08$ \\
\hline 2 & $142.33 \pm 1.74$ & $318.50 \pm 2.96$ & $301.00 \pm 2.35$ \\
\hline 4 & $151.33 \pm 2.26$ & $306.50 \pm 1.65$ & $302.66 \pm 3.48$ \\
\hline 8 & $153.16 \pm 3.13$ & $322.66 \pm 3.08$ & $301.16 \pm 1.58$ \\
\hline 12 & $158.00 \pm 2.80$ & $327.00 \pm 2.50$ & $303.16 \pm 2.24$ \\
\hline 24 & $164.66 \pm 3.23$ & $340.80 \pm 3.63$ & $303.16 \pm 2.24$ \\
\hline
\end{tabular}

It is worth mentioning here that from data given in Table III and IV, it is also observed that Caralluma tuberculata reduced blood glucose levels more efficiently when administered in cooking oil than in capsule form i.e. at 2, $4,8,12$ - and 24-hours interval ( $p<0.001)$.

\section{Discussion}

In the present study, experimentation was done on different forms of Caralluma tuberculata i.e. crude extract and carbon tetrachloride fractions $\left(\mathrm{CCl}_{4}\right)$ in both capsule and in cooking oil to find out the form in which it is more effective as hypoglycaemic agent. When crude extract of Carallumain in a dose of $200 \mathrm{mg} / \mathrm{kg}$ body weight was administered in capsule form to diabetic rabbits, it caused highly significant reduction in blood glucose level after 2 hours of treatment, which continued up to 12 hours. Whereas, when carbon tetrachloride $\left(\mathrm{CCl}_{4}\right)$ fraction of Caralluma (100 mg/kg body weight) in capsule form was administered, highly significant reduction in blood glucose level was seen from 2 hours after treatment till 24 hours. Carbon tetrachloride $\left(\mathrm{CCl}_{4}\right)$ fraction of Caralluma $(100 \mathrm{mg} / \mathrm{kg}$ body weight) in cooking oil was also administered to diabetic rabbits. Beside significant reduction $(p<0.001)$ in blood glucose levels, it was found that Caralluma tuberculata administered in cooking oil reduced blood glucose levels more than that administered in capsule form. 
Unlike other studies, we used carbon tetrachloride fraction in capsule and cooking oil forms to compare their efficacy. The reported information regarding effects of medicinal plants in developing hypoglycaemia was observed at maximum 6 hours after administration of dose. In our study, strategy was adopted to evaluate effect after two hours of administration of dose and again after 4, 8, 12 and 24 hours. It was aimed to see how long the dose effect of Caralluma sustains on blood glucose level. As far as the underlying mechanism for hypoglycaemia is concerned, it is deduced from various studies that this plant might contain multiple hypoglycaemic constituents, causing the release of insulin by stimulating beta cells and hence resulting in significant drop in blood glucose levels. Moreover, they may also have insulin like orally active substance, as Momordica charantia vegetable. ${ }^{16}$

In addition, drugs such as biguanides are known to produce hypoglycaemia by decreasing gluconeogenesis and promoting glycolysis. ${ }^{17}$ Biguanides prevent hypoglycaemia in normal individuals by balancing the increased peripheral glucose utilization and additional glucose output of hepatocytes. So, it is suggested that Caralluma may contain specific constituents, which cause hypoglycaemia either by increasing the insulin secretion or mimicking insulin action. ${ }^{18}$ Different substances, like anterior and posterior pituitary hormones, prostaglandins, corticosteroids etc and plants like Trigonella foenum produces hypoglycaemia by different means and mechanisms. ${ }^{19}$ Therefore, establishment of detailed phytochemical and pharmacological profile of this plant is necessary to identify the exact underlying mechanism of hypoglycaemia.

\section{Conclusion}

Caralluma tuberculata lowered the blood glucose levels in mammalian model of rabbits and turned out to be more effective when taken with cooking oil. However, the efficacy of herbal medications needs to be further evaluated by well designed, controlled clinical studies.

\section{Recommendations}

1. Conduct Randomized Controlled Trial to establish efficacy and safety of Caralluma tuberculata as an oral hypoglycemic agent in diabetic patients

2. The possible toxicity of the crude and $\mathrm{CCl} 4$ extracts of Caralluma tuberculata should be investigated.

\section{References}

1. Guariguata L, Whiting $D R$, Hambleton I, Beagley J, Linnenkamp U, Shaw JE. Global estimates of diabetes prevalence for 2013 and projections for 2035. Diabetes Research and Clinical Practice. 2014;103(2):137-49

2. Shera AS, Jawad F, Maqsood A. Prevalence of diabetes in Pakistan. Diabetes Research and Clinical Practice. 2007;76(2):219-22

3. Akhtar MS, Ramzan A, Ali A, Ahmad M. Effect of Amla fruit (Emblica officinalis Gaertn.) on blood glucose and lipid profile of normal subjects and type 2 diabetic patients. International Journal of Food Sciences and Nutrition. 2011;62(6):609-616

4. Patel D, Prasad S, Kumar R, Hemalatha S. An overview on antidiabetic medicinal plants having insulin mimetic property. Asian Pacific Journal of Tropical Biomedicine. 2012;2(4):320-330.

5. Ponnusamy S, Ravindran R, Zinjarde S, Bhargava S, Ravi Kumar A. Evaluation of traditional indian antidiabetic medicinal plants for human pancreatic amylase inhibitory effect in vitro. Evidence based Complementary and Alternative Medicine: eCAM; 2011:515647.

6. Vaidya AD, Devasagayam TP. Recent Advances in Indian Herbal Drug Research Guest Editor: Thomas Paul Asir Devasagayam Current Status of Herbal Drugs in India: An Overview. Journal of Clinical Biochemistry and Nutrition. 2007;41(1):1-1

7. Katzung B, Master S,Trevor A. Blood glucose. Basic and clinical pharmacology. United States:MC Grew Hell. 2012;12th Ed.1245p.

8. Rehman R.U., Chaudhary M.F., Khawar K.M, Lu G, Mannan A, Zia M. et al. In vitro propagation of Caralluma tuberculata and evaluation of antioxidant potential.Biologia. 2014; 69:341-345.

9. Poodineh J, Feizabad AK, Nakhaee A. Antioxidant activities of Caralluma tuberculata on streptozotocin induced diabetic rats. Drug Development Research. 2015;76(1):40-47.

10. Alamgeer, Ahmad T, Malik MNH, Mushtaq MN, Qayyum R, Khan $A Q$, Akhtar $S$. et al. Evaluation of antihypertensive effect of aqueous methanol extract of Caralluma tuberculata 
n.e.br in sprauge dawley rats. Tropical Journal of Pharmaceutical Research. 2015;14(3): 455-462.

11. Mudrikah, Bibi Y, Tabassum S, Zahara K, Bashir T, Haider S. Ethnomedicinal and pharmacological properties of Caralluma tuberculata N. E. Brown. Pure Appl. Bio. 2015; 4(4):503-510.

12. Adnan M, Jan S, Mussarat $S$, Tariq A, Begum S, Afroz A. et al. A review on ethnobotany, phytochemistry and pharmacology of plant genus Caralluma $\mathrm{R}$. Br.Journal of Pharmacy and Pharmacology. 2014; 66: 1351-1368.

13. Ahmad B, Abbas SJ, Hussain F, Bashir S, Ahmad D. Study on Caralluma tuberculata nutritional composition and its importance as medicinal plant. Pak. J. Bot. 2014; 46(5): 1677-1684.

14. Liu T, Zhao H, Li J. Korantzopoulos P, Li J. Rosiglitazone attenuates atrial structural remodelling and atrial fibrillation promotion in alloxan-induced diabetic rabbits. Cardiovascular Therapeutics. 2014; 32(4): 178-183.

15. Mushtaq, M.N, Bashir S, Ullah I, Karim S, Rashid M, Hayat Malik MN., et al., Comparative hypoglycemic activity of different fractions of Thymus serpyllum $L$. in alloxan induced diabetic rabbits. Pak J Pharm sci, 2016; 29(5): 1483-1488

16. Efird JT, Choi YM, Davies SW, Mehra S, Anderson EJ, Katunga LA. Potential for improved glycemic control with dietary momordica charantia in patients with insulin resistance and pre-diabetes.Int. J. Environ. Res. Public Health. 2014; 11(2): 2328-2345.

17. Drahota Z, Palenickova E, Endlicher R, Milerova $M$, Brejchova J, Vosahlikova M. et al. Biguanides inhibit complex I, II and IV of rat liver mitochondria and modify their functional properties. Physiol Res. 2014; 63: 1-14.

18. Sharma RA, Singh B, Singh D. Ethnomedicinal, pharmacological properties and chemistry of some medicinal plants of Boraginaceae. Indian J. Med. Plants Res. 2009;3(13):1153-75

19. Swaroop A, Bagchi M, Kumar P, Preuss HG, Tiwari K, Marone PA. et al. Safety, efficacy and toxicological evaluation of a novel, patented anti-diabetic extract of Trigonella Foenum-Graecum seed extract. Toxicol Mech Methods. 2014; 24(7):495-503. 